\title{
Of Politics and Anarchy: Zimbabwe's 2008 Run-off Presidential Elections in Context
}

\author{
Zein Kebonang*
}

Botswana- UPenn Partnership, University of Pennsylvania, Gaborone, Botswana

\begin{abstract}
Following the "successful" subvertion of the electoral process by President Mugabe in the 2008 run-off presidential elections in Zimbabwe and the subsequent formation of the Government of National Unity, this paper attempts to offer insights that may explain President Mugabe's refusal to honor the outcome of the electoral process and the subsequent degeneration into authoritarian and repressive politics. Based partly on international relations theories and theories on the nature of political authority in Africa, this paper argues that the conduct of President Mugabe and the ruling Zimbabwe African National Union-Patriotic Front (ZANU-PF) can best be explained from three "perspectives": the self-preservation; the apologetic and the neo-patrimonial perspective.
\end{abstract}

Keywords: Zimbabwe African National Union-Patriotic Front (ZANU-PF), Sanctions, Dialogue, Power Sharing, Joint Operations Command (JOC), Democracy, Elections, Movement of Democracy Change (MDC), Government of National Unity (GNU), Civil Society Organizations (CSOs).

\section{INTRODUCTION}

In an attempt to hold onto power, the Zimbabwean government, acting first through the Zimbabwean Electoral Commission (ZEC) and then state security apparatus, not only caused the witholding of the $29^{\text {th }}$ March 2008 Presidential election results won by Morgan Tsvangirai of the opposition Movement of Democratic Change (MDC) but in finally releasing them, unleashed a campaign of violence and terror against supporters and activists of the opposition MDC thereby forcing the party to pull-out of the scheduled 27 June 2008 run-off presidential elections. This conduct by President Mugabe and the Zimbabwean government not only attracted international condemnation but was also in clear violation of the country's commitments under a number of treaties such as the African Charter on Human and Peoples' Rights and the International Covenant on Civil and Political Rights (ICCPR). These treaties enjoin member states to protect their citizens against inhuman, cruel and degrading treatment. They also compel states to investigate and prosecute any such violations.

Relying on international relations theories, this paper offers possible insights into the transformation of Zimbabwe into authoritarian politics. To give context to the arguments being made, the paper starts by giving a brief history of elections in Zimbabwe. This is followed by a look at the power sharing agreement concluded by Zimbabwe's warring parties in 2008. Next, the paper considers the country's descend into anarchy and the international community's response to the crisis. The paper then offers three possible explanations to President Mugabe and ZANU-PF's refusal to yield power

"Address correspondence to this author at the Botswana- UPenn Partnership, University of Pennsylvania, Gaborone, Botswana; Tel: 267-3685508; Fax: 267-3170957; E-mails: zkebonang@hotmail.com;

kebonang@bta.org.bw despite their electoral defeat. The explanations or perspectives offered are what I term the "self-preservation" perspective, which looks at the role of the state security forces in state institutions, politics and human rights violations; the "apologetic" perspective which seeks to explain the government's conduct from a historical or colonial standpoint, and the "neo-patrimonial" perspective, which looks at the nature of political authority in post-independent Africa and the importance of state-power and patronage in politics. This is then followed by a conclusion.

\section{ELECTORAL PRACTICE IN ZIMBABWE}

Zimbabwe attained independence in 1980 after a protracted eight year guerilla war. The 1980 national elections which were won by ZANU-PF saw President Mugabe being inaugurated as the country's first Prime Minister (Chigora and Guzura 2011:22; Chiviru 2009). Although a liberal democracy at independence and allowing other political parties to participate in the country's electoral process and political space, ZANU-PF was able to create a "one-party" state in 1987 when it assimilated its former off-shot, the Zimbabwe African People's Union (ZAPU) (Chiviru 2009). Presidential elections have been held in 1990, 1996 and 2002 while legislative elections were held in 1980, 1985, 1990, 1995, 2000 and 2005 (Schlee 2011:5; Chigora and Guzura 2011:21). Except for the 2008 elections, all other elections were won by ZANU-PF. In 2008, despite massive electoral fraud, ZANU-PF lost its parliamentary majority and presidential elections to the MDC (Chigora and Guzura 2011:21; Masunungure 2010:90). It is believed that had President Mugabe not rigged the 2002 Presidential elections by arresting oppostion figures, closing polling stations in MDC strong holds and detaining international election observers, he would have lost the presidential elections then (Makumbe 2002; Kobayashi 2010; Masunungure 2009: 80). 
With the loss of the 2008 elections came violence. The violence that defined the 2008 elections however started much earlier and seem to have been precipitated largely by the formation of the MDC in 1999. This clearly appears to be the case as elections held post the establishment of MDC have been characterized by wide-spread violence, intimidation, fraud, media manipulation and the killing of political opponents (Chiviru 2009; Sachikonye 2009; Kobayashi 2010; Makumbe 2002).

In 2008, when President Mugabe lost the presidential elections to Tsvangirai, security forces intervened by unleashing terror and violence in order to ensure that President Mugabe won the run-off presidential elections. In the first round of the presidential elections, President Mugabe had secured 43.24 percent against Tsvangiari's 47.87 percent (Masunungure 2010:96; Chigora and Guzura 2011). The authenticity of these results was not helped by ZEC's withholding of the results for more than a month after voting ballots had been counted. As if President Mugabe and ZANU-PF were privy to the outcome, they declared their readiness for a run-off election even before the results were officially announced (Masunungure 2010:82).

The run-off elections which were provided for under the constitution in the event that the first election proved inconclusive, became a militarized affair. In the words of Masunungure (2010:83), "the security forces, rather than the ruling party were in the forefront, spearheading the march to the 27 June run-off'. With the intervention of the army, the systematic killing of opposition supporters and the detention of opposition political leaders, Tsvangirai succumbed and withdrew from the run-off elections thereby handing President Mugabe the presidency. The military had thus, succeeded in delivering the presidency to ZANU-PF (Masunungure 2010: 93; Chiviru 2009; Sachikonye 2009).

Despite Mugabe's contrived electoral success, the economy continued on its free fall. Inflation skyrocketted, food, medical and fuel shortages became pronounced and the once vibrant agricultural sector collapsed. With investors fleeing and the economy on its knees, ZANU-PF succumbed to international pressure and concluded a power sharing agreement with both the MDC and smaller MDC faction led by Arthur Mutambara.

\section{THE POWER SHARING AGREEMENT}

The power sharing agreement signed on the $18^{\text {th }}$ September 2008 ushered in a government of national unity (GNU) (Mutisi 2011; Chigora and Guzura 2011:21; Masunungure 2009). The power sharing agreement however was not an act of benevolence on the part of ZANU-PF. The United States (US), which had earlier imposed sanctions against Zimbabwe for its land grabbing policy, swiftly called for more sanctions against the country following the disputed presidential elections. Canada and France declared that they would only recognize the 29th March 2008 Presidential elections which had been won by the opposition while Germany encouraged its companies to pull-out of Zimbabwe.

But while the reaction by the international community or the West in calling for smart sanctions against President
Mugabe and key government officials were encouraging in signaling the international community's unwillingness to countenance blatant human right violations as a means to retaining political power, the African Union's (AU) voice was muted. In 2008 for instance, when some AU member states such as Gabon, Botswana, Liberia and Nigeria questioned the legitimacy of President Mugabe and the country's right to participate in African forums, the AU at its Summit held at Sharm-el-Sheik, Egypt, opted instead to call for the formation of a government of national unity (Abwao and Cowell 2008). In failing to condemn President Mugabe, the AU effectively endorsed his legitimacy as the President of Zimbabwe. This endorsement flew in the face of reports by observer teams such as the Pan African Parliament (PAP) which had stated that the run-off presidential elections did not represent the will of the Zimbabwean people as these were marred by high levels of intimidation, violence, displacement of people, abductions and loss of life (Human Rights Watch 2008).

The resolution by the AU only confirmed its ineffectiveness in dealing with its member states and revealed the premium it attached to group solidarity. By empathizing with ZANU-PF, the AU gave ammunition to the notion that the AU, just like its predecessor, the Organization of Africa Unity (OAU), is in fact, purely a place where African dictators go to find solace. Surprisingly, even the New Partnership for Africa's Development (NEPAD) which was hailed as representing new beginnings for the African continent in terms of holding states accountable to internationally acceptable and agreed standards of governance was silent on the Zimbabwean crisis.

Despite what appeared to be reluctance by African leaders to deal decisively with President Mugabe, as noted, a power-sharing agreement between ZANU-PF and the two MDC formations was finally concluded in September 2008 thereby giving birth to a new GNU (Chigora and Guzura 2011:23; Machakanja 2010:3). In terms of the Agreement, President Mugabe remained the country's President and chair of the cabinet while Mr. Tsvangirai became the country's Prime- Minister; cabinet vice chairperson and head of a new Council of Ministers that supervises the work of cabinet (Mutisi 2011; Masunungure 2009).

Arthur Mutambara of the smaller MDC assumed the position of deputy prime minister. The rest of the Cabinet positions were to be divided equally between the parties. Although the unity government has held up, President Mugabe has not only refused to give up control of the powerful ministries (Home Affairs, Defence, Information, and Foreign Affairs), but is now calling for elections and the disbandment of the GNU (Mutisi 2011; Masunungure 2009).

\section{STATE POWER AND ANARCHY}

As noted, the period preceeding the formation of the GNU was characterised by violence, displacement, human rights violations and a collapsed economy. The campaign of terror by ZANU-PF started in earnest shortly after the party's failed to garner enough support on a new constitution it had proposed in the 2000 national referendum. The opposition to the referendum has been spearheaded by civil 
society organizations which included trade unions, human rights organizations, independent media houses and student organizations (Chigora and Guzura 2011: 20; Sachikonye 2009; Booysen 2002).

In response to the referendum failure, President Mugabe and ZANU-PF not only ignited a campaign of terror against the Zimbabwean people but also encouraged and applauded the invasion and seizure of white owned farms by its "war veterans" (Kobayashi 2011; Masunungure 2009:81; Makumbe 2002). The invasion of white-owned farms which destroyed the country's vibrant agricultural sector, was followed by a slum-clearing campaign which was in reality intended to punish city dwellers for having voted against the constitutional referendum (Kobayashi 2011; Booysen 2002).

The imposition of sanctions which followed did not immediately prompt President Mugabe and ZANU-PF to embark on a road of reform. In the face of sanctions, hyper inflation rates and severe food shortages, President Mugbabe continued to insist that the economy was doing well; "our economy is a hundred times better than the average African economy. Besides South Africa, what country is as good as Zimbabwe?... What is lacking now are goods on the shelvesthat is all" (Holland 2008).

Apart from being in a state of denial, ZANU-PF also sought to deflated attention from its failed land grabbing policies by attempting to undermine the credibility of the MDC by projecting it as a puppet of the Western world and denouncing its members as "sellouts" (Mutisi 2011; Kobayashi 2010; Chiviru 2009). The country's response to sanctions and the criticism of the June 2008 run-off presidential elections was incredibly one of defiance. President Mugabe's Press Secretary, George Charamba, told the media that the West could "go hang a thousand times" for criticizing Zimbabwe's presidential election run-off (Musengeyi 2008, Chiviru 2009; Masunungure 2010).

\section{THE POWER OF SANCTIONS AND DIALOGUE}

Although the US and other Western countries imposed sanctions in reaction to the crisis in Zimbabwe, the AU and Southern African Development Community (SADC) followed a parallel process and engaged in dialogue with Zimbabwe. The former President of South Africa, President Mbeki was mandated to engage with the warrying parties in Zimbabwe. Despite his impartiality being questioned and little progress being made under his "quite diplomacy" strategy, he was eventually able to broker the power-sharing agreement following the disputed 2008 Presidential elections.

The GNU that was eventually established therefore came in large measure because of the power of sanctions and dialogue. Several international law and international relations scholars have posited a number of theories in an attempt to explain why states comply with their international obligations. These theories have ranged from the transnational legal process theory developed by Koh (1997), the reputational theory developed by Guzman (2002) and the management theory developed by Chayes and Chayes (1995), to mention but three. I suggest that while these theories do help us in understanding why President Mugabe and ZANU-PF eventually came to the negotiating table, they do not shed light on why a number of actors in Zimbabwe-President Mugabe, ZANU-PF and the security forces- would want to hold on to power despite ZANU-PF electoral defeat. Based on the theories on the nature of political authority in Africa discussed in the succeeding section, I offer three possible explanations for this conduct.

According to the legal process theory, states obey international law/norms as a result of repeated interactions with other actors, or as Koh (1997:2602) puts it, "[through] a complex process of institutional interaction whereby global norms are not just debated and interpreted, but ultimately internalized by domestic legal systems". Whilst it is not clear to what extent states or domestic courts will internalize international norms, the transnational theory is insightful to the extent that it envisions states learning best practices from their interaction with others.

Guzman (2002:1827) on the other hand, posits that states comply with international law/agreements both out of concern for their reputation and for fear of sanctions. He calls his theory, a "reputational model of compliance" (Guzman 2002:1825). Chayes and Chayes (1995) in their "New Sovereignty", meanwhile, reject the use of sanctions in securing compliance with a treaty obligation. They contend that coercive enforcement mechanisms are not only rarely used to ensure compliance with international treaties, but are also likely to be ineffective when used (Chayes and Chayes 1995:33; see also Crossen 2004:482; Frischmann 2003:738). They argue that management tools, such as transparency, reporting, verification and monitoring, dispute resolution and capacity building are the key to designing a regime which encourages compliance (Chayes and Chayes 1995:25; see also, Crossen 2004:482; Frischmann 2003:738).

As with the reputation theory, the Chayes' management theory claims that the incentive for compliance is not so much a nation's fear of sanctions, as fear of diminution of status through loss of reputation (Koh 1997:2636; Crossen 2004:488). Reputation matters in that though states can pursue their own interests without regard to the reactions of others, they are restrained in their conduct because "there are too many audiences, foreign and domestic, too many relationships present and potential, too many linkages to other issues to be ignored" (Chayes and Chayes 1995:119).

Although both the reputation and the management theories identify the loss of reputation as an important variable in explaining why states comply with their international obligations, they differ on whether sanctions play any role in this compliance mix.

Whilst making a case for his reputation theory, Guzman (2002:1866) acknowledges that there may be instances where punitive sanctions are the only means of achieving optimal results. For example, sanctions would be appropriate in dealing with states that continually violate their international obligations. For this reason, he argues that despite any shortcomings that punitive sanctions may have, they should not be dismissed as otiose (Guzman 2002:1868). According to this theory, reputation and sanctions are to be regarded as complements rather than substitutes. 
Chayes and Chayes (1995:25) meanwhile contend that compliance with treaties is maintained through an "iterative process of discourse among parties, the treaty organization and the wider public". In rejecting the use of sanctions as a basis for inducing compliance, they maintain that states have a general propensity to comply with their international obligations and that the principal source of non-compliance is not usually wilful disobedience by states but usually stems from: (1) the ambiguity and indeterminacy of treaty language, (2) limitations on capacity of parties to carry out their undertakings and (3) the temporal dimension of the social, economic and political changes contemplated by regulatory treaties (Chayes and Chayes 1995:10; 1993:188). Hence, the use of sanctions or an "enforcement model" of compliance must be replaced with a "management model" in which;

\begin{abstract}
"Performance that seems for some reason unsatisfactory represents a problem to be solved by mutual consultation and analysis, rather than an offense to be punishable... persuasion and argument are the principal engines of this process, but if a party persistently fails to respond, the possibility of diffuse manifestations of disapproval or pressures from other actors in the regime is present in the background" (Chayes and Chayes 1995:26).
\end{abstract}

Although the need to maintain a good reputation can provide the required impetus for states to comply with international norms/obligations, as noted in the preceding section, states are not always necessarily driven by reputational concerns in the conduct of their international relations. In fact, states often have mixed reputations. Accordingly, a loss of reputation may not in itself provide a sufficient prod for states to comply.

Whilst a country may without doubt suffer a loss of reputation as a result of its failure to comply with its obligations, such a state may in fact be notorious for noncompliance. Equally, the loss it suffers may not be sufficiently high as to alter its behaviour. Therefore, even though reputation matters, it is not decisive in matters of state relations. Unless accompanied by the use of sanctions, the loss of reputation may not in and by itself provide the necessary push towards compliance. As Downs, Rocke and Baarsoom (1996:397) argue in their critique of the management theory, while coercion may not be a panacea, it cannot be ruled out as irrelevant.

Similarly as Koh (1997:2639) points out, by emphasizing the power of the managerial model and the weakness of the enforcement models, the management theory, "creates a false impression that the two are alternatives when in fact these two strongly complement one another, the managerial model succeeds not just because of the power of discourse but also because of the possibility of or 'shadow' of sanctions, however remote that prospect might be".

\section{EXPLAINING ZIMBABWE'S DEFIANCE}

Although dialogue, sanctions and reputational concerns as posited by the different theories on why states comply with or conform to international norms do provide some explanation and insight as to why a country may or may not defy international norms, I suggest in this section that these principles do no shed light on President Mugabe and ZANUPF's violent refusal to surrender power despite their electoral defeat. I contend that President Mugabe and ZANU-PF's conduct can best be understood from atleast three perspectives: "self-preservation"; "apologetic" and the "neopatrimonial" perspectives.

\section{THE SELF PRESERVATION PERSPECTIVE}

This perspective is best understood by considering the role of state security forces and key government officials in human rights abuses in Zimbabwe. State security forces in Zimbabwe have often participated in politically motivated human rights violations in the country. In the 1980 s, they were involved in systematic and widespread atrocities in Matebeleland and Midlands provinces aimed at destroying support for the then ZAPU led by Joshua Nkomo, which at the time was perceived as a viable alternative to ZANU-PF (Human Rights Watch 2008:10; Rupiya 2011; Chigora and Guzura 2011).

According to a report by the Catholic Commission for Justice and Peace, and the Legal Resources Foundation, the army through its Fifth Brigade, carried out over 3000 extrajudical executions; 7000 beatings, 10000 arbirtary detentions, and countless and unexplained disappearances in Matebeleland and Midland provinces (Human Rights Watch 2008:10). In 1988 rather than prosecute those implicated in these human rights violations, the government provided a general amnesty to state security forces implicated in these abuses (Human Rights Watch 2008:61).

ZANU-PF's total control of the organs of state has allowed to militarize practically all sectors of government and state (Kobayashi 2010; Sachikonye 2009; Bratton and Masunungure 2008:44). Instead of being apolitical, the military and the security sector have taken on the role of key political supports of ZANU-PF (Chiviru 2009:5; Masunungure 2010:82).

The infusion of the ruling party to the state has meant that party and state structures at all levels have become conflated. This has resulted in the party being supreme over the state (Masunungure 2010:82; Kobayashi 2010). Under this phenomenon, all formal organs of the state "including the military and security services are closely linked to the party without being officially integrated into it" (Masunungure 2010:82; Bratton and Masunungure 2008:48).

The infusion of the state, security forces and ZANU-PF became more evident in the period leading to the run-off presidential elections when following President Mugabe's defeat in the 29th March 2008 Presidential elections, ZANU$\mathrm{PF}$ "came to the conclusion that the party had failed in the march to 29 March and therefore that the military should lead the march to 27 June" (Masunungure 2010:93). The militarization of Zimbabwe politics in the service of ZANUPF and President Mugabe is described by Brian Raftopoulos as follows;

“...it is quite clear that President Robert Mugabe's real strenght is the coercion 
which comes out of the army and the liberation war veterans. He is using it to the full and the militarisation will be to his benefit even if the opposition does well in any elections which might take place" (quoted in Masunungure 2010:82)

Thus, it was the military that ensured Mugabe's success in the run-off presidential elections as its interventon effectively disregarded the outcome of the electoral process and the will of the Zimbabwean people. As Kobayashi (2010) puts it, while "votes...won MDC a seat at the table [of the power sharing government], ZANU-PF's guns...kept Robert Mugabe at its head....[and] MDC remains unlikely to displace Mugabe as long as ZANU-PF controls the state security organs".

Prior to the March 2008 Presidential elections and in clear reference to Tsvangirai, the army had already publicly declared their loyalty for President Mugabe by vowing not to salute or recognize any leader who did not have "liberation credentials" (Rupiya 2011; Masunungure 2009, Chiviru 2009 and Human Rights Watch 2008:18). More recently, Brigadier General Nyikayaramba told a weekly Zimbabwean paper that the military had wanted national elections 2011 to ensure ZANU-PF success and added that "truly speaking, I am in ZANU-PF and ZANU-PF is in me and you can't change that" (Rupiya 2011).

Support for President Mugabe has not been limited to mere public statements by senior security personnel, but has been expressed through the provision of logistical support to war veterans and ZANU-PF supporters. War veterans and youth militia reportedly operated from army bases and used army trucks and pickups to carry out raids on the homes of MDC and opposition activists and supporters generally (Human Rights Watch 2008: 26, Chiviru 2009).

Government officials including some members of parliament have also been actively involved in these violations. Peter Chanetsa and Rueben Marumahoko, both ZANU-PF members of Parliament and Senate respectively are reported to have told a gathering of ZANU-PF supporters immediately after the March 2008 elections that "people voted the wrong way, so people must be beaten thoroughly so that no one will ever vote MDC again" (Human Right Watch 2008:34).

Many of the human rights violations by state security forces have occurred under the umbrella of a secretive body of military and police commanders known as the Joint Operations Command (JOC) (Masunungure 2010:81; Sachikonye 2009; Human Rights Watch 2008). The JOC is made up of the heads of Zimbabwe's security forces: the Zimbabwe Defence forces, police, the central intelligence organization and the prison service (Masunungure 2010:81; Sachikonye 2009; Human Rights Watch 2008).

It was the JOC which had within days of the $29^{\text {th }}$ March 2008 Presidential elections "decided to deploy a strategy of delay and violence in order to hold onto the all-important executive" (Alexander and Tendi 2008; Masunungure 2009:81). Thus, the militarization of politics in Zimbabwe has happened in collusion and with the blessing of the ruling ZANU-PF and its political allies.
With security forces having participated in atrocities in Zimbabwe, self interest and preservation simply dictates that they should hold on to power by whatever means. For them, without Mugabe and ZANU-PF in power, they are likely to face war-crimes prosecution for their roles in the political violence that has and still engulfs the country. As George Katito of the South African Institute for International Affairs states, "what is at stake for the Zimbabwean military generals is being brought to justice for more than 20 years of human-rights abuses," (cited in Lindow 2008).

To be sure the military and ZANU-PF's human rights violations have been helped in no small measure by adherence to the principle of state sovereignty. This principle provides that a state has a right to act as it deems fit in all matters internal to it without interference from external forces (see, for instance, Kebonang 2005; Gerhart 2003).

The doctrine of non-interference has been a guiding principle of states' interaction under international law. Article 4, Chapter 1, of the United Nations Charter provides for instance that "all Members shall refrain in their international relations from the threat or use of force against the territorial integrity or political independence of any state, or in any other manner inconsistent with the purposes of the United Nations".

Likewise, the AU Constitutive Act provides in its Article 4 (g) that the Union shall function in accordance with the principle of "non-interference by any Member state in the internal affairs of another". The Union will only interfere in a member state under Article $4(\mathrm{~h})$ pursuant to a decision of the Assembly in respect of grave circumstances, namely; war crimes, genocide, and crimes against humanity.

Thus, unless the conduct complained of falls under the provisions of Article 4 (h) of the Act, the circumstances under which the AU can interfere in the internal affairs of a state are fairly specific and narrow. Deference to the principle of state sovereignty however has served to ensure that ZANU-PF's monopoly of violence continues unabated.

\section{THE APOLOGETIC PERSPECTIVE}

The "apologetic" perspective seeks to explain the government's conduct from a historical or colonial viewpoint. For Zimbabwe, independence in 1980 came after a prolonged liberation struggle against the then oppressive minority white government of Ian Smith. For a number of scholars, the experiences acquired under the colonial rule directly account for the manner in which power is being exercised in post-independent Africa.

According to Claude Ake (1991); Muna Ndulo (1999); Naomi Chazan (1993); Charles Rowley (2000); Bruce Berman (1998) and Seyoum Hameso (2002) among others, African governments have simply come to mirror their former colonial masters in the way they govern or conduct themselves. They argue that during the colonial period the state was authoritarian, coercive and undemocratic in the way in which it operated. Ake (1991:32) in particular, states that during the colonial period, political discourse not only excluded democracy but even the idea of good governance and politics was reduced to a clash of one exclusive claim of power against another. 
Likewise, Ndulo (1999) contends that in bequeathing African governments with a bureaucracy that emphasized hierarchy, compliance and discipline, the colonial authority neglected to address other important concerns such as public accountability, responsiveness and participation.

Thus, upon independence, "African Presidents [simply] replaced the colonial Governor in fact and in deeds" (Ndulo 1999). Oppression, repression, lack of accountability and exclusion became embraced as legitimate ways of ruling (Hameso 2002; Berman 1998:329; Ake 1991:33) with state power remaining for the most part "as absolute and arbitrary as that of the colonial powers that had preceded it" (Rowley 2000:139). By this logic therefore, it can be argued that President Mugabe's conduct is perfectly justified for the only lessons he "learnt" from Ian Smith were those of oppression and arbitrariness.

The above view however does not explain why countries such as Ethopia and Liberia, which were never colonized became autocratic or why countries like Botswana which was under British rule pursued a more democratic route. It is contended here that what is happening in Zimbabwe is simply a failure of political leadership and nothing more. This is particularly the case as President Mugabe had in the initial years of his presidency adopted a more reconcialiatory path than the current retributory one.

\section{THE NEO-PATRIMONIAL PERSPECTIVE}

The neo-patrimonial perspective provides yet another possible explanation for President Mugabe and ZANU-PF degeneration into authoritarian politics. Unlike in many Western countries, the state in Africa is often viewed as a source for private accumulation of wealth. President Mugabe's economic mismanagement and the use patronage to allocate state resources has allowed senior government and state security service officials to become wealthy and complacent in human rights abuses.

The term neo-patrimonialism as used, is derived from the concept of patrimonial authority. In patrimonial political systems, power is not necessarily exercised for the common good of society but is rather self-serving, with leaders being more concerned about their self-interest or the interest of their group than public welfare. Under this system, authority is shaped by the ruler's preferences rather than any codified system of laws (Kebonang 2005:6; Bratton and Van De Walle 1997:61; 1994:458). This being the case, the ruler "ensures the political stability of the regime and personal political survival by providing a zone of security in an uncertain environment and by selectively distributing favors and material benefits to loyal followers" (Bratton and Van De Walle 1997:61).

In return for material rewards, followers or "clients" are expected to mobilize political support for the incumbent leader and to refer all decisions upwards as a mark of deference to the leader or patron (Bratton and Van De Walle 1994:458).

Just as in patrimonialism, the right to rule in neopatrimonial regimes is ascribed to an individual rather than an office. The difference however, is that neo-patrimonialism occurs not in a traditional environment but within the context of a modern state. It blends elements of the patrimonial, traditional rule with features of rational-bureaucratic or modern rule (Kebonang 2005:6; Alence 2004:165; Taylor 2003; Gibson 2002:209; Bratton and Van De Walle 1997:62; 1994:458; Le Vine 1980:666). Outwardly, the state has all the features of a Weberian rational-legal system, with a clear dichotomy between the public and the private realm, with written laws and a constitutional order (Van De Walle 2004:44). But permeating the entire formal political and administration chain is a dense network of dependent relationships.

At the apex of both systems is a leader (the "strongman", "big man" or "supremo"), who not only dominates the state apparatus but also stands above its laws (Bratton and Van De Walle 1997:62; Le Vine 1980:662). Officials occupy bureaucratic positions less to perform public services than to acquire personal wealth and status (Kebonang 2005:6; Van De Walle 2004:44; Bratton and Van De Walle 1997:62; Bayart 1993:70). In other words, office holders almost systematically appropriate public resources for their own use. Political authority is maintained by the allocation of state resources through clientelist practices, including patronage, various forms of rent seeking and prebendalism (Kebonang 2005: 6; Van De Walle 2004:44; Gibson 2002:209).

Although elected in 1980 under free and fair elections, once in office President Mugabe centralised power by establishing a one party system and defeating the opposition through state sponsored violence, fraudulent arrest and intimidation (Rupiya 2011; Chiviru 2009). Since independence Zimbabwe has known no ruler but President Mugabe.

Over the years and in line with an elaborate patronage system, ZANU-PF has deployed military personnel to strategic positions in various state institutions responsible for governance such as the judiciary, ZEC, the Delimitation Commission, local government institutions, and statecontrolled companies such as the National Railways of Zimbabwe (NRZ), the Grain Marketing Board (GMB) and the National Oil Company of Zimbabwe (NOCZIM) (Rupiya 2011; Masunungure 2010:82; Chiviru 2009).

This system of patronage has now resulted in a situtation where the economy is being controlled by the military and ZANU-PF operatives, thus making "their economic interests just as powerful as their fears for accountability for human right abuses" (Rupiya 2011). Thus, for President Mugabe and ZANU-PF, ceding power would be tantamount to giving up the goose that lays the golden egg! Self-interest under the patrimonial rule simply dictates that they must hold on to power even if it means dismantling and bankrupting a once functioning state.

\section{CONCLUSION}

While sanctions and reputational risks may be important in ensuring compliance with international norms and standards, they are by no means determinitive of state conduct or behaviour. In many setting, personal interest may override greater public interest. Control of institutions of power and the ability to shape the actions of others through 
either through patronage or coercion may influence the direction that a country takes.

As the Zimbabwean case study demonstrates, without the necessary checks and balances in place, power can so easily be misused by those who exercise it for personal ends. Until security forces stay politically neutral and non-partisan, it is unlikely that any election will usher in a democractically elected government. Statements by the military declaring loyalty to ZANU-PF and President Mugabe undermine all efforts at having a legitimately elected government and are in essence a mutiny in support of ZANU-PF. As noted, it was the army that intervened in 2008 to ensure President Mugabe remained in office. At a bare minimum therefore, the military must desist from politics if Zimbabwe is to move forward. Unless this happens, the unity government is unlikely to transition Zimbabwe to democratic governance.

Lastly, although the theories on compliance are useful in helping us understand what may induce compliance, it is often the micro factors that have the greatest bearing. In a country such as Zimbabwe where there have been no effective checks and balances; where human rights violations have been applauded by the state, self interest and preservation simply dictates that the ruling elite must hold on to power by whatever means necessary.

For President Mugabe and ZANU-PF, reputational concerns, the imposition of sanctions and engaging in meaningful dialogue are inconveniences that are outweighed by the security and protection accorded by the office. For them, ceding power will not only mean a loss of privilege and access to state resources but also a real possibility of prosecution for human rights violations. It is in this context that President Mugabe's refusal to yield power must be understood.

\section{CONFLICT OF INTEREST}

None declared.

\section{ACKNOWLEDGMENT}

None declared.

\section{REFERENCES}

Abwao, K., \& Cowell, A. (2008). African Union calls for settlement in Zimbabwe. Retrieved November 3rd, 2011, from http://www.nytimes.com/2008/07/02/world/africa/02zimbabwe.htm 1? $\mathrm{r}=1$ \&oref=slog

Ake, C. (1991). Rethinking African Democracy. Journal of Democracy, 2(1), 32-44.

Alence, R. (2004). Political Institutions and Developmental Governance in Sub-Saharan Africa. Journal of Modern African Studies, 42 (2), 163-187.

Baldauf, S. (2008). African Union Calls for Unity in Zimbabwe. The Christian Science Monitor.

Bayart, J.F. (1993). The State in Africa: The Politics of the Belly. United Kingdom: Longman Publishers.

Booysen, S. (2002). The Dualities of Contemporary Zimbabwean Politics: Constitutionalism versus the Law of Power and the Land, 19992002. African Studies Quarterly.

Bratton, M., \& Masunungure, E. (2008). Zimbabwe's Long Agony. Journal of Democracy, 19(4), 41-55.

Berman, B. (1998). Ethnicity, Patronage and the African State: The Politics of Uncivil Nationalism. African Affairs, 97(388), 305-341.
Bratton, M., \& Van de Walle, N. (1997). Democratic Experiments in Africa: Regime Transitions in Comparative Perspective, United Kingdom: Cambridge University Press.

Bratton, M., \& Van de Walle, N. (1994). Neo-Patrimonial Regimes and Political Transitions in Africa. World Politics Journal, 46 (4), 453489.

Chayes, A., \& Chayes, A.H. (1995). The New Sovereignty: Compliance with International Agreements. Cambridge: Harvard University Press.

Chazan, N. (1993). Between Liberalism and Statism: African Political Cultures and Democracy, in L. Diamond (ed), Political Culture and Democracy in Developing Countries. London: Lynne Rienner Publishers.

Chigora, P., \& Guzura, T. (2011). The Politics of the Government of National Unity (GNU) and Power Sharing in Zimbabwe: Challenges and Prospects for Democracy. African Journal of History and Culture, 3(2), 20-26.

Chiviru, T. (2009). The Security- Development Nexus: An analysis of the potential impact of Security Sector Reform on the Reconstruction process in Zimbabwe. Idasa.

Crossen, T. (2004). Multilateral Environment Agreements and the Compliance Continuum. Georgetown International Environment Law Review $16,473-500$.

Frischmann, B. (2003). A Dynamic Institutional Theory of International Law. Buffalo Law Review 51, 681-809.

Gerhart, P.M. (2003). The two constitutional visions of the world trade organization. University of Pennsylvania Journal of International Economic Law 24, 1-75.

Gibson, C.C. (2002). Of Waves and ripples: Democracy and political change in africa in the 1990s. Annual Review of Political Science Journal 5, 201-221.

Guzman, A.T. (2002). A Compliance-Based Theory of International Law. California Law Review 90, 1823-1887.

Hameso, S. (2002). Issues and Dilemmas of Multi-Party Democracy in Africa. Retrieved November 15th, 2011, from http://www.westafricareview.com/vol3.2/hameso.html

Holland, H. (2008). A glimpse inside Mugabe's World. Retrieved September 4th, 2011 from http://news.bbc.co.uk/2/hi/africa/7470959.stm

Human Rights Watch Report (2008). Bullet for Each of You” StateSponsored Violence since Zimbabwe's March Elections.

Johnson, R.W. (2008). African Unity Cracks over Zimbabwe as leaders reject 'quiet diplomacy'. Retrieved November 4, 2011, from http://www.timesonline.co.uk/tol/news/world/africa/article4232127 .ece

Kebonang, Z. (2005). Promoting Foreign Direct Investment in Africa through Moral leadership. Africa Insight, 35(1), 3-13.

Kobayashi, D.B. (2010). Peril at the Polls: Lessons from Zimbabwe's 2008 Elections. Sanford Journal of Public Policy 1(1).

Koh, K. (1997). Why Do Nations Obey International Law. Yale Law Journal 106, 2599-2630.

Le Vine, V. (1980). African patrimonial regimes in comparative perspective. Modern African Studies, 18(4), 657-673.

Lindow, M. (2008). Zimbabwe under Military rule. Retrieved November 23rd, 2011, from http://www.time.com/time/world/article/0,8599,1813656,00.html

Machakanja, P. (2010). National Healing and Reconciliation in Zimbabwe: Challenges and Opportunities. Institute of Peace Leadership and Governance, Africa University, Zimbabwe.

Makumbe, J.M. (2002). Zimbabwe's Hijacked Election. Journal of Democracy,13(4), 87-101.

Masunugure, E.V. (2010). A Militarized Election. The 27 June Presidential Run-off. Retrieved November 10th, 2011, from http://www.kas.de/upload/dokumente//2010/05/Defying_5.pdf

Masunungure, E.V. (2009). Zimbabwe's Power Sharing Agreement. Department of Political and Administrative Studies, University of Zimbabwe.

Mutisi, M. (2011). Beyond the signature: Appraisal of the Zimbabwe Global Political Agreement (GPA) and Implications for Intervention. Accord 4, 1-7.

Ndulo, M. (1990). Democracy, Institution Building, and Poverty in Africa. Retrieved November 10, 2011, from http://www.dse.de/ef/poverty/ndulo-in.htm

Pannell, I. (2008). Military runs Mugabe's Campaign. Retrieved November 17 , 2011 from http://news.bbc.co.uk/1/hi/world/africa/7449704.stm 
Rowley, C.K. (2000). Political Culture and Economic Performance in SubSaharan Africa. European Journal of Political Economy, 16 (1), 133-158.

Rupiya, M. (2011). The Military Factor in Zimbabwe's Political and Electoral Affairs. Retrieved January 10th, 2012, from http://www.swradioafrica.com/Documents/The\%20Military\%20Fa ctor\%20in\%20Zimbabwe.pdf

Sachikonye, L. (2009). Between Authoritarianism and Democratization: The challenges of a transition process in Zimbabwe. Institute for Development Studies. University of Zimbabwe.
Schlee, B. (2011). Economic Crisis and Political Apathy in Zimbabwe: The Impotent Society. Arnorld-Bergstraesse Institute, Germany.

Taylor, I. (2003). Big Ideas and Big Men: Neo-Patrimonialism, the African State and the New Partnership for Africa's Development. University of Botswana.

Van de Walle, N. (2004). Economic Reforms: Patterns and Constraints, in E. Gyimhan-Boadi (ed), Democratic Reform in Africa: The Quality of Progress, London: Lynne Rienner Publishers.

\section{(C) Zein Kebonang; Licensee Bentham Open.}

This is an open access article licensed under the terms of the Creative Commons Attribution Non-Commercial License (http://creativecommons.org/licenses/by-nc/3.0/) which permits unrestricted, non-commercial use, distribution and reproduction in any medium, provided the work is properly cited. 